\title{
An Architecture for Improving Hajj Management
}

\author{
Mohammad Yamin ${ }^{1}$ and Moteb Ayesh Albugami ${ }^{2}$ \\ ${ }^{1}$ Department of MIS, King Abdulaziz University, Saudi Arabia, \\ ${ }^{2}$ Faculty of Business Adminstration, Tabuk University, Saudi Arabia \\ myamin@kau.edu.sa, malbugami@ut.edu.sa
}

\begin{abstract}
The effective management of crowded events such as the Muslim Hajj in Saudi Arabia and the Hindu Kumbh in India continues to remain a challenge mainly due to uncontrollable buildup of crowds or mismanagement. Despite regular occurrence of catastrophes such as stampedes and fires, resulting in significant loss of lives, there are no international binding standards for controlling and managing large crowds. Indeed, the use of advanced technology, including tracking and monitoring tools, and sensor and biometric identification methods, can assist towards better crowd management but technology alone cannot be a solution to overcrowding. Because of the congestion, resulting from overcrowding, timely cleaning and sanitation becomes unmanageable, which causes spread of diseases. This article discusses some factors which are critically important and provide an architecture for better management of Hajj.
\end{abstract}

Keywords: Management, Crowd, Hajj, Kumbh, Stampedes, RFID, Sensor Networks, Biometric, pilgrims, tawaf.

\section{Introduction}

In the last decade alone, thousands of people have perished in stampedes, fires and other incidents resulting from overcrowding or mismanagement of large gatherings of people. Ironically most of the crowded events happen to be religious in nature. On $13^{\text {th }}$ October 2013, more than one hundred people died due to overcrowding on a bridge in India [1]. On $10^{\text {th }}$ February 2013, dozens of people were crushed to death in Kumbh [17]. On the eve of 2013, more than sixty people were killed and hundreds injured in Ivory Coast [2]. Excessive death toll (over eleven hundred) and injuries (over two and a half thousands) in a building collapse in Bangladesh on $24^{\text {th }}$ April, 2013 was also partly due to overcrowding [18]. In Hajj alone, during the last twenty years, several stampedes and fires have resulted in thousands of deaths, the most recent [3] being in October 2012. To analyze and describe the problems of overcrowding, we have chosen the case of Hajj, which is an annual event involving a gathering of more than three million with very intense activities.

The Hajj is a pilgrimage to Makkah in Saudi Arabia that takes place every year during $8^{\text {th }}-12^{\text {th }}$ Dhulhijja, a month in the Islamic (lunar) calendar. Every year millions of pilgrims from more than one hundred and fifty countries perform Hajj. Although

K. Liu et al. (Eds.): ICISO 2014, IFIP AICT 426, pp. 187-196, 2014.

(C) IFIP International Federation for Information Processing 2014 
the Hajj rituals span only four fixed days, but partly due to limited air and sea transportation, many of the pilgrims spend four to six weeks in and around Makkah (Mecca) and Madinah (Medina), the two holiest cities for Muslims. The Hajj is a unique, very complex, challenging and costly exercise to manage as it involves frequent mass movement of more than three million pilgrims. Some of the problems and aspects of Hajj can be found in [10], [11], [12], [13], [14] and [15]

The most critical factors in crowd management are the extent of the crowd and its management. To minimize the chances of stampedes and other catastrophes, event organisers need to limit the crowds to acceptable levels. However, there is no binding international standard for setting a limit on the number of people which could be allowed to gather in a specified space or area. Event organization would become significantly easier to manage if such standards were agreed upon and implemented. Crowd management can also be improved significantly with the help of sensor and biometric technology, tools and gadgets. Some of the intensely crowded events like the Hajj often involve simultaneous movement of the entire congregation, which creates problems of transportation and uncontrollable buildup of crowd. In such situations, tracking, accessibility and identification of pilgrims becomes very difficult. Many of the sensor and wireless devices available today, including Radio Frequency Identification (RFID) [5] can be used for controlling and monitoring the movement of crowds. These technologies are now being widely used for improving management and administration of many business functions. However, these technologies are still going through a transitional phase [9] and one would hope to see significant refinement of them to become usable and effective for managing very large and dense crowds. Nevertheless, these technologies in their present form could have been used in saving thousands of precious lives in many of the past incidents of stampedes and fires. A description of ubiquitous technologies including RFID, sensor networks, biometric and scanning devices can be found in [5].

There are serious health issues for crowded events with a span of three or more days, if cleaning and disposal of rubbish cannot be carried out regularly. Lack of cleaning gives rise to the growth of dangerous bacteria, which has been witnessed in some cases [6]. Another serious health risk is from the mismanagement of the pilgrims carrying communicable and contagious viruses, bacteria and diseases. Due to inability to control entry, many pilgrims may carry deadly bacteria such as HIV Aids and Hepatitis. Many of these infected pilgrims may not be known to the management and hence cannot be isolated. Indeed the infected pilgrims must be isolated from the rest of the pilgrims. For managing the health and wellbeing of the pilgrims, including those infected with contagious bacteria, the RFID technology can play a very significant role [21].

In this paper we present and analyze a number of problems of hajj management, and offer some solutions including architecture for improving the management. These solutions can indeed be applied in many other and similar crowded events such as Kumbh. 


\section{The Hajj Management Issues}

Hajj is a set of highly complex and intense activities which makes it a very challenging event to manage. Overseas pilgrims start arriving in Saudi Arabia five weeks before the actual hajj period. Late arrivals stay back for up to five weeks after the event. The hajj rituals however only span over four days, from 8-12 of the Arabic (lunar) month of Dhulhijja. The problems and challenges of Hajj are generally not known to many researchers mainly because of the entry restrictions and poor press and media coverage.

\subsection{Pilgrims Numbers}

Due to an overwhelming number of requests, which cannot be accommodated, people (including the Saudi citizens) are restricted to perform Hajj once in five years. However, this moratorium has so far not been successfully implemented. Current facilities for hajj are adequate only for two million people. One of the main problems for the Hajj mangers is to deal with a large number of illegal pilgrims. Makkah region, which has a population of about two million, largely contributes to the illegal pilgrims. According to the governor of Makkah [16], in 2012, up to 3.65 million pilgrims performed hajj, which nearly doubled the maximum accommodation capacity. Some other sources, including eye witness accounts of congestions put these figures even much higher which demonstrates that the number of the hajj pilgrims is often uncontrollable. Most of the expatriates, living in the kingdom of Saudi Arabia, are always very eager to perform hajj every year and many of them happen to be illegal migrants. Presence of the unauthorized pilgrims, especially the illegal immigrants, is a cause of great concern, particularly in relation to law and order agencies. The hajj managers do not have any personal and health data for these pilgrims. Hence they also pose serious health risks, severely strain the pilgrim movement, sometimes causing stampedes. During the 2012 Hajj, due to overcrowding, walking on roads became very strenuous and sometimes resulted in minor stampedes. In the case of an emergency, due to the lack of data, illegal pilgrims are very vulnerable

\subsection{Visa and Immigration}

Anyone outside Saudi Arabia, intending to perform Hajj, applies for a visa through a travel agent in their country of residence by furnishing information and undergoing some medical examination and immunisation. The hajj visa is granted by the Saudi government if the visa conditions are met. Once a Hajj visa is granted, each pilgrim is assigned to a Hajj Management group, known as Munazzim, who are responsible for organising travel and accommodation before, during and after the hajj. The Munazzim groups are the official representatives of the Ministry of Hajj.

For an overseas pilgrim, there are very strict visa requirements for entering in the kingdom of Saudi Arabia. The foreign pilgrims are mainly processed at Jeddah and 
Madinah airports, which are about ninety and four hundred kilometers away from Makkah, respectively. Jeddah is not only the designated airport of Makkah but also has the main sea port where hundreds of thousands of pilgrims, mainly from Africa, are processed. So far there is only one $4 \times 4$ lane road link between Jeddah and Makkah but currently a rail link is also under construction. Most of the pilgrims also visit Madinah, which houses the grand mosque of the prophet Muhammad and is also his final resting place. After the immigration processing, the pilgrims are required to hand over their passports to their Munazzim and travel to their hotels in Makkah or Madinah in the care of the Munazzim group.

\subsection{Assemblies in Mina, Arafat and Muzdalifah}

As part of the core activities of Hajj, all pilgrims are required to spend some time in Mina, Arafat and Muzdalifah. The tent city of Mina [7], separated from Makkah by about seven kilometers of very thick hills, has historically predefined perimeters. It covers an area of about twenty square kilometers and has thousands of nonflammable tents that can accommodate about one and half million pilgrims. All pilgrims are required to spend three days in Mina. By a very simple arithmetic calculation, it is easy to determine that Mina cannot accommodate more than two million pilgrims.

The Valley of Arafat [19] hills are about twenty kilometers away from Mina. All pilgrims must spend the best part of the day of $9^{\text {th }}$ Dhulhijja there. This area has a capacity to accommodate about two million pilgrims. Muzdalifah is a small village between Mina and Arafat. All pilgrims are required to spend the night of $9^{\text {th }}$ Dhulhijja in Muzdalifah, which nowadays can accommodate up to a maximum of one million people as a large portion of its area has been consumed by the multiple roads running between Mina and Arafat. On their way back from Arafat valley, all pilgrims are required to spend the night of the $9^{\text {th }}$ Dhulhijja in the open space, previously a hill, near the town of Muzdalifah. The space in Muzdalifah is much smaller than that of Arafat or Mina. There is not enough space for even one million people. As a result, roads get jammed for many hours and many pilgrims cannot make it to Muzdalifah until the morning of the next day.

The journey from Mina to Arafat on the morning of the $9^{\text {th }}$ of Dhulhijja and then from Arafat to Muzdalifah in the evening is a very complex exercise. The hajj management ought to be congratulated for transporting more than three million people from Mina to Arafat and back on the same day. Since 2010, there is a train service linking Mina, Muzdalifah and Arafat; however this service can transport only a fraction of the three million passengers. Sometimes, the number of pilgrims' swells to four millions as it did in 2012. In desperate situations, many pilgrims would find alternative accommodation in adjoining townships, roadsides, hills, pathways, and rooftops, endangering their lives and those of others. 


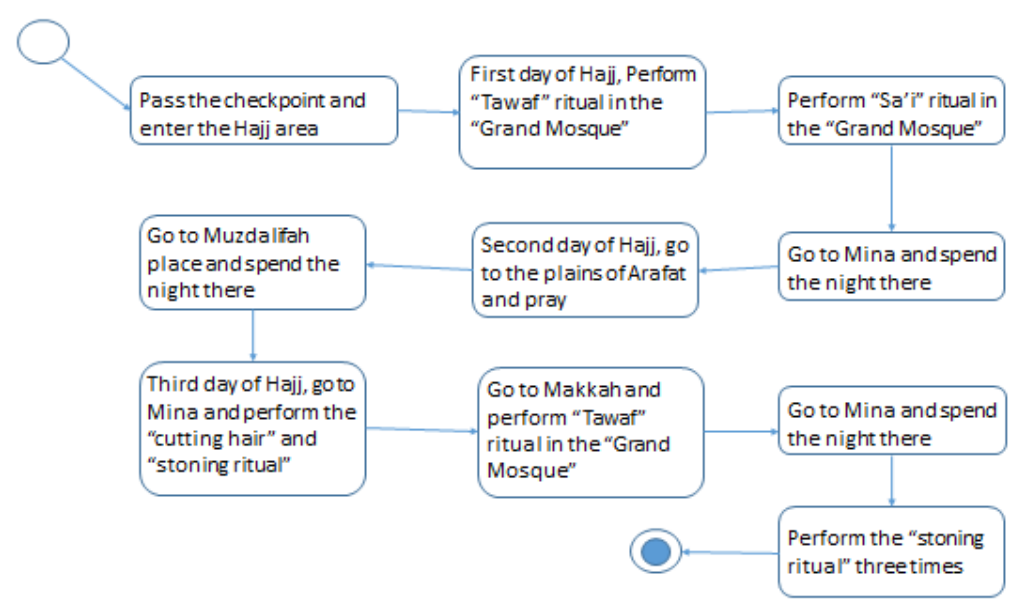

Fig. 1. Diagram of core activities of hajj

\subsection{Core Rituals of Hajj}

Fig 1 shows a diagram of the core activities of Hajj. On the $8^{\text {th }}$ day of Dhulhijja, the first day of hajj, all pilgrims travel to, and spend the night in the tent city of Mina. On the $9^{\text {th }}$ day of Dhulhijja, all pilgrims travel to the Valley of Arafat Mountains, located about twenty kilometers from Mina. Assembly in the Arafat valley on the afternoon of the $9^{\text {th }}$ day of Dhulhijja is mandatory for all pilgrims. After the sunset, all pilgrims must travel to Muzdalifah, a hill town between the valley of Arafat and Mina. At Muzdalifah pilgrims are normally required to offer prayers and to spend the night in the open space. In the morning of the $10^{\text {th }}$ day of Dhulhijja, all pilgrims arrive back in Mina where they perform a set of rituals. These rituals include symbolic stoning, known as 'Rami' at sites of devils, popularly known as Jamarat, and a journey to grand mosque in Makkah where they perform tawaf (circumvolution) of Kaaba and offer prayers in the holy mosque. On the $11^{\text {th }}$ day of Dhulhijja, pilgrims remain in Mina and perform a set of rituals including another act of stoning at Jamarat. On the $12^{\text {th }}$ day of Dhulhijja, after another set of stoning rituals, the hajj is completed and the pilgrims return back to their hotels or homes. After a few days, foreign pilgrims gradually start returning back to their home countries. Some pilgrims have to wait for up to five weeks to return to their home countries.

\subsection{Health Risks and Lost Pilgrims}

Currently hajj permissions may be granted for people suffering from serious medical conditions. However, the management of pilgrims suffering from contagious and communicable diseases is highly desirable. It is extremely dangerous to allow pilgrims carrying HIV, hepatitis, swine flu, bird flu, and tuberculosis to live with other pilgrims. Such pilgrims must be identified and isolated. On the other hand, lack 
of cleaning and sanitation due to intense crowding, especially during the four days of hajj, causes many pilgrims to develop a cough and fever.

As the hajj involves frequent mass movement and activities, many pilgrims disperse from their groups and lose their way. Due to communication problems, lack of education, congestion, poor network reception and many other reasons these pilgrims go on missing for days and sometimes weeks. Some of these pilgrims are injured and require urgent medical attention. Currently, pilgrims carry a nonelectronic wristband, which only identifies a pilgrim belonging to group of thousands of pilgrims under a Munazzim.

\section{Some Solutions}

Although the Saudi Arabian government has provided extensive and superior infrastructure to facilitate Hajj but still, some problems of congestion, resulting in disasters like stampedes, fires and spread of diseases persist. In the case of road congestion, extra infrastructure just increases the usage and doesn't reduce congestion [4]. Thus a good infrastructure is not necessarily a viable substitute for effective management. Here we present some solutions to the problems, including an architecture, to improve the management of hajj.

\subsection{Controlling the Pilgrim Numbers}

In order to be able to effectively manage hajj, it is absolutely necessary to limit the number of pilgrims to an acceptable level. Some extraordinary measures are required to be implemented for stopping illegal pilgrims. The lack of these measures has witnessed a swelling crowd in 2012. Learning from the problems encountered earlier, during the hajj of 2013, the management ran a very successful campaign of effective advertisements at all levels of media vowing to very severe punitive measure for unauthorized pilgrims. These measures did succeed in limiting the number of pilgrims to about two million, but still there were no significant reduction in the number of illegal pilgrims from Makkah region. To minimize the chances of locals contributing to the catastrophes, it is highly desirable to organize crowd management training programs and encourage the people, especially the ones from Makkah region, to participate.

\subsection{Pilgrim Tracking and Identification}

Currently many organizations and businesses are using RFID chips with a sensor or a WiFi network to track and monitor people and products. For example, passports of many countries are now RFID enabled, which leads to immigration processing without human intervention. Some RFID tags [8] such as shown in Fig 2 can be used to replace traditional wristbands. The RFID tags can carry vital data and can be supported with a sensor, GPS or a $3 \mathrm{G}$ network to relay data to the data center. An account of the description, usage and usefulness of RFID can be found in [5]. 

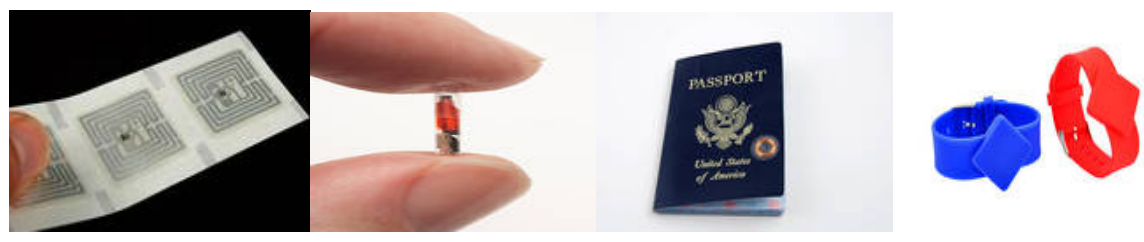

Fig. 2. RFIDs for human use and tracking

\subsection{Prevention of Spread of Diseases}

There are two prerequisites for preventing the spread of diseases during hajj namely, controlling the number of illegal pilgrims and availability of data of every pilgrim's health including diseases that can affect others. By preventing illegal pilgrims, the management can effectively get the hajj precinct regularly cleaned and hence prevent the outbreaks of bacteria that normally develop within seventy-two hours of nondisposal of garbage. Instead of preventing pilgrims with diseases like HIV Aids, tuberculosis and Hepatitis, hajj management should create a secluded isolation area for the infected pilgrims. Socially and religiously, it would be very hard to deny pilgrimage to people on their deathbeds. So if they cannot be stopped, they should be properly managed.

The problems of crowding in Mina, Arafat and Muzdalifah are dependent on pilgrim numbers, religious interpretations and infrastructure. It is simply impossible to accommodate two million people in Muzdalifah, prompting religious decree to ease the overcrowding. Some traffic congestion problems may ease in coming years once the rail links (under construction) between Jeddah, Makkah, Mina, and Madinah become operational. Currently, there are hundreds of towers and many other large buildings under construction to meet the increasing demand of accommodation.

\subsection{Operations Overview}

While there are a lot of issues associated with the Hajj, the most important is the need to managing the crowd and facilities during the Hajj period. The component diagram in Fig 3 shows an overview of the proposed operations architecture.

As shown in Fig 3, the crowd controller will be responsible for monitoring and managing, transportation, health care services, security services and ritual sites. The transportation is managed by scheduling, based on the number of people in a ritual site at given time. In case of emergency, the controller will inform and request help from health care and security services. The controller will liaise with the security services in a two ways communication, where they can report and receive reports about security issues. The controller receives information about the situation and status in the various ritual sites. Accommodation will be available for all pilgrims upon arrival in the ritual sites, of Mina, Arafat and Muzdalifah, which would be equipped with the required facilities. Buses and trains would transport pilgrims 


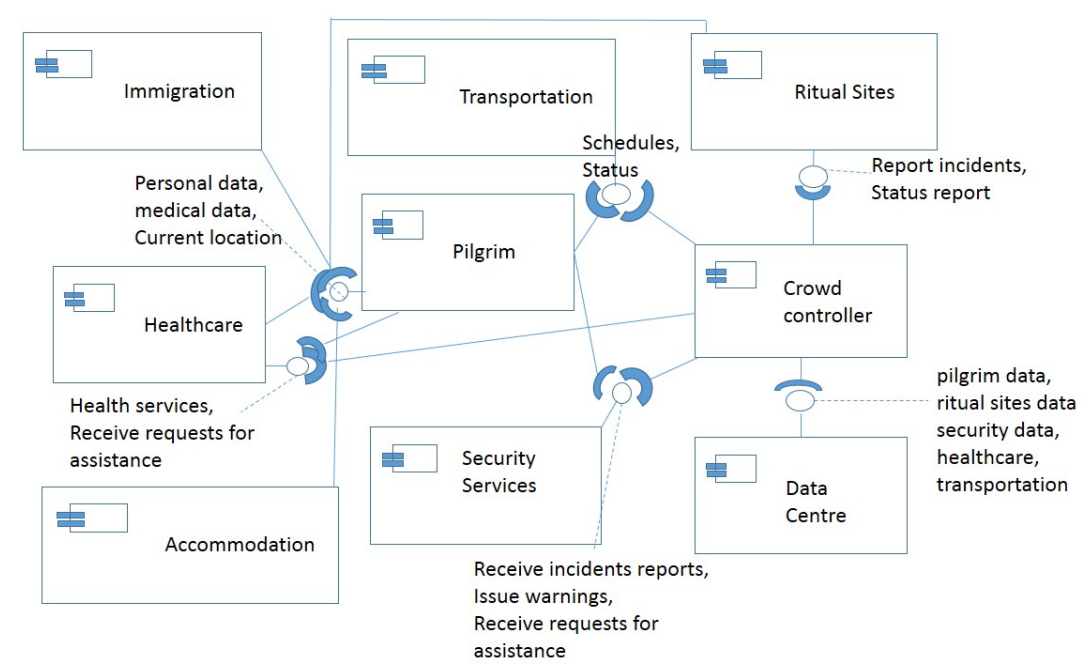

Fig. 3. An Overview of the Architecture

between sites. The rituals sites would be monitored and receive instructions or request help from the controller. Additionally, the controller would monitor the movements of individuals and crowd for security, health and traffic reason.

The architecture and other solutions proposed in this paper can be useful in managing many other crowded events such as Kumbh and Badrinath Yatra [20].

\section{Conclusions}

People continue to die due to mismanagement of crowded events. The culture of blame game needs to change by squarely making the local management and government responsible for all overcrowding and preventable catastrophes in their jurisdiction. Surely, better and improved infrastructure may help in checking overcrowding but infrastructure alone is not sufficient to prevent hazardous incidents. There is a need for well-coordinated management of crowds with modern tools and technology. The technology, if used as part of a whole solution, can be very effective in controlling crowds but may not bring desired results if used in a standalone mode as is the case of hajj or Kumbh management. The hajj rituals are based on Abrahamic traditions mentioned in the holy Quran which were enacted by Mohammed, the prophet of Islam. Thus being deeply enshrined in religious teachings and faith, some changes cannot be implemented unless approved by the clerics.

Technological solutions, irrespective of their sophistication, become ineffective because of the ignorance, which prevails in almost all religious gatherings. Incidentally, most of the large gatherings are religious in nature and sadly most of the stampedes are associated with religious gatherings. These religious assemblies gather people from diverse ethnicities, beliefs and cultures, which make it very difficult to 
make simple changes against sectarian religious perceptions. However, through persistent cross-cultural consultation, and discussions at national and international levels, managers of such events can bring many desirable changes.

Acknowledgment. The inspiration for this article has come from personal experiences of the authors who have performed hajj several times, and who have also participated in many other crowded events including the Kumbh. The authors acknowledge support from the faculty of Economics and Administration of the King Abdulaziz University. The authors also acknowledge the help provided by various individuals and organisations involved in the hajj management including the Hajj Research Centre in Makkah and the Ministry of Interior of Saudi Arabia.

\section{References}

1. ABC Online News, Scores dead after bridge stampede near Hindu temple in India, http: / / www . abc.net.au/news/2013-10-13/scores-killed-inindian-bridge-collapse-during-hindu-gathering/5019484 (retrieved January 10, 2014)

2. CNN, Ivory Coast mourns 60 killed in New Year's stampede (January 2, 2013), http: //edition.cnn.com/2013/01/01/world/africa/ ivory-coast-deaths (retrieved January 10, 2014 )

3. Daily Mail, 50 pilgrims' dead in Hajj stampede, http: / /www dailymail.co.uk/news/article-07141/50-pilgrimsdead-Hajj-stampede.html (retrieved February 15, 2013)

4. Duranton, G., Turner, M.A.: The fundamental law of road congestion: Evidence from US cities. The American Economic Review 101(6), 2616-2652 (2011)

5. Finkenzeller, K.: RFID Handbook: Fundamentals and Applications in Contactless Smart Cards, Radio Frequency Identification and Near-Field Communication, 3rd edn. Wiley (2010)

6. McConnell, J.: The Lancet Infectious Diseases. Mass gatherings health Series, vol. 12(1), pp. 8-9 (January 2012)

7. Mina, Saudi Arabia, http://en.wikipedia.org/wiki/ Mina,_Saudi_Arabia (retrieved January 10, 2014)

8. Rfid stock photos and images, http: / / www. fotosearch.com/ photos-images/rfid.html (retrieved February 23, 2014)

9. Talevski, A., Wu, C., Chang, E.: Wireless Sensors, SOA and Web Based Approaches for Remote Operation and Control. In: 7th IEEE International Conference on Industrial Informatics, INDIN (2009)

10. Yamin, M., Ades, Y.: Crowd Management with RFID \& Wireless Technologies. In: Proceedings of First International Conference on Networks \& Communications. IEEE Computer Society Washington, DC (2009)

11. Yamin, M., Huang, X., Dharmendra, S.: Wireless \& Sensor Technology and Crowd Management. Journal of Cooperation among University, Research and Industrial Enterprises 2(1) (April 2009)

12. Yamin, M., Masoud, M., Huang, X., Sharma, D.: RFID Technology and Crowded Event Management. In: Proceedings of International Conference on Intelligent Agents, Web Technologies and Internet Commerce, Vienna, December 10-12 (2008) 
13. Yamin, M.: A Framework For Improved Hajj Management And Future Research. ENTIC Bull. 2(08) (2008)

14. Yamin, M.: A Framework For Improved Hajj Management And Future Research. In: Proceedings of International Engineering Convention Jeddah, Saudi Arabia, March 10-14 (2007)

15. Yamin, M.: Wireless Systems to Manage Large Congregations, Proceedings of Keynote Addresses and Invited Lectures. In: 2nd International Conference on Wireless Communications and Sensor Networks, Allahabad India, pp. 17-19 (2006)

16. Saudi Gazette (November 10, 2012), http: / / www . pressdisplay.com/pressdisplay/viewer.aspx (retrieved January 10, 2014)

17. The Guardian, Kumbh Mela stampede leaves dozens of Hindu pilgrims dead - video (retrieved February 15, 2013), http: / /www. guardian.co.uk/world/video/ 2013 /feb/11/kumbh-mela-stampede-hindu-video (retrieved January 10, 2014 )

18. Wikipedia, Savar Building Collapse (2013), http://en.wikipedia.org/wiki/2013_Savar_buil-ding_collapse (retrieved February 15, 2013)

19. Wikipedia, Mount Arafat, http://en.wikipedia.org/wiki/ Mount_Arafat (retrieved January 10, 2014)

20. Wikipedia, Badrinath, http://en.wikipedia.org/wiki/Badrinath (retrieved February 15, 2013)

21. Yao, W.: The use of RFID in healthcare: Benefits and barriers. In: Proceedings of IEEE International Conference on RFID-Technology and Applications, RFID-TA (2010) 